\title{
LIQUIDITY IN ASIAN FINANCIAL MARKETS: CROWDING OUT OR SPILLOVER EFFECT
}

\section{SONAL THUKRAL ${ }^{1}$, RAHUL SIKKA ${ }^{*}$}

1. Delhi Technological University, India

* Corresponding Author: Research Scholar, Delhi School of Management, Delhi Technological University, Shahbad Daulatpur, Main Bawana Road, Delhi-110042, India. $₫$ rahulsikka123@yahoo.co.in

\begin{abstract}
The paper attempts to explore the relationship between the stock market and the corporate bond market, with a focus on the inter-dependency of liquidity between the two markets. The study employs a panel dataset to assess the impact of stock market liquidity on the corporate bond market liquidity for the top five Asian economies (ranked by GDP) for the period 2008-2017. In contrast to a limited number of earlier studies that reported a spillover effect of liquidity among the markets for stock and government bonds, the results of the present study convey that an increase in stock market liquidity tends to eat up the liquidity of the corporate bonds, even after controlling for government bond yield and inflation rate changes. The findings indicate a crowding-out effect instead of a spillover effect, as indicated by related studies. The 'flight-to-quality' argument provides one possible explanation of liquidity moving away from one market to the other. This implies that if regulators' policies are focused on developing only one type of market, it may crowd out the liquidity and the development of the other market. The study suggests that the government focus more on the corporate bond market, which is yet to flourish in the Asian markets as compared to its stock market counterparts. The paper is one of the few attempts that focus on the corporate bond market and its liquidity and aims to ignite a debate on the possible linkages between the liquidity of the corporate bond market and the stock market.
\end{abstract}

Keywords: Liquidity, corporate bond market, stock market, turnover ratio, crowding out, spillover effect

\section{Introduction}

Financial Market liquidity has garnered increased interest in the past with close lens on the stock market. While focusing on the stock market, some studies have explored the effect of market liquidity on the prices and returns in the market (Amihud, 2002; Amihud and Mendelson, 1986; Jacoby et al., 2000; Jones, 2002; Jun et al., 2003; Pástor and Stambaugh, 2003). At the same time, others have explored factors that influence liquidity in the stock market (Correia and Amaral, 2014; Grossman and Miller, 1988; Hameed et al., 2010; Heflin et al., 2002; Kim et al., 2006). With regards to the bond market, the extant literature has analyzed the determinants of bond market development, but most of the work has focused on the size or capitalization of the market (Bhattacharyay, 2013; Eichengreen and Luengnaruemitchai, 2011; Maurya and Mishra, 2016; Mu et al., 2013; Smaovi et al., 2017; Teplova and Sokolova, 2018), and only a few studies examine the liquidity aspect of the bond market. Goyenko et al. (2011) and Gündüz et al. (2018) explore the factors that influence liquidity in the bond markets, while Lin et al. (2011) study the impact of liquidity on corporate bond returns. Further, the literature exploring the interlinkages of liquidity between the bond market and the stock market is almost missing as per our knowledge. Chordia et al. (2005) found liquidity shocks to be positively correlated across the two markets. In contrast, Goyenko and Ukhov (2009) found bond market 
liquidity acting as a channel between monetary policy effects and the stock market liquidity, spilling over the money supply shocks from one market to another.

The limited studies that examine liquidity interlinkages between the bond and the stock markets overlook the corporate bond market and limit their focus to the treasury bond markets. Moving away from previous studies and in an attempt to fill this large gap, the present study attempts to explore the relationship between stock market liquidity and corporate bond market liquidity. Previous studies have explained stock market liquidity as a determinant of prices and returns of the stock market; however, our study differs by studying the stock market liquidity as a determinant of corporate bond market liquidity.

Further, the limited studies that focus on the liquidity of the corporate bond markets have concentrated on well-developed markets such as the United States (Bao et al., 2011; Chakravarty and Sarkar, 1999; Lin et al., 2011). Liquidity in the Asian corporate bond markets, which has been suffering (Sharma, 2001) has often escaped the attention of the researchers. To address this issue, our paper focuses on a cross country sample of Top five Asian economies.

A well-functioning corporate bond market makes it easier for corporations to avail credit and reduce the pressure on the banks leading to a reduction in the risk to the economy (Hakansson, 1999). A developed bond market promotes effective fundraising, which assists in stimulating economic activities (Hue and Trâm, 2019). Some studies establish a causal link between bond market development and economic growth (Fink et al., 2003; Pradhan et al., 2015), further emphasizing the importance of a bond market. Despite the importance of the bond market established in the literature, studies exploring its different aspects are relatively scarce, thereby heightening the importance to examine the functioning of these markets deeply. One of the significant reasons for scant literature can be attributed to the lack of trading level data as pointed out by Harrison (2002).

Asian economies have been growing at an impressive rate. Currently, the share of Asian economies in the global output is at $38 \%$, rising from $26 \%$ in the 2000 s and 2020 , Asian economies are expected to surpass rest of the world in terms of Purchasing Power Parity (Romei and Reed, 2019). Asian corporate bond markets have been growing in size, measured by the number of outstanding issues, for the past few years, and in March 2018, reached a valuation of $\$ 5.3$ trillion (CARE Ratings Ltd., 2018). However, when we compare it with the US market, which stands at more than $\$ 8.8$ trillion, Asian countries seem to have lagged. The vast potential in the Asian markets provides impetus to explore the corporate bond market scenario in Asia.

To study the effect that stock market liquidity has on the liquidity in the corporate bond market, the present study employs a panel of top five Asian economies ranked by their GDP for the period 2008 to 2017. Utilizing insights from the extant literature, our study also controls for two other variables that could have a possible effect on the corporate bond market liquidity - government bond yield and inflation rate in the economy. The results of the study show a negative relationship between the corporate bond market liquidity and the stock market liquidity. The negative relationship observed in our results points towards a crowding-out effect between the two markets explaining that higher liquidity in the stock market seems to eat up the liquidity in the corporate bond market. The relationship remains significant, even after controlling for government bond yields and inflation rates in the economy.

The contribution of the present study lies in its attempt to draw the attention of the researchers to the highly overlooked area, the corporate bond market liquidity. Existing literature assesses the liquidity linkages between the treasury bond markets and stock markets; however, our study explores the linkages of liquidity pertaining to the corporate bond market and the stock market. The crowding-out effect observed in the study provides an interesting aspect of the dynamic relationship between the two markets. Previous studies, ostensibly similar to our present study that examines the linkages between the stock market and bond market liquidity (Chordia et al., 2005; Goyenko and Ukhov, 2009) have found evidence of a spillover effect rather than the crowding-out 
effect. The present study also observes that stock market liquidity in our overall sample surpasses the liquidity in the corporate bond market, possibly owing to the lucrativeness of the stock market for investors. The lucrativeness can be attributed to the efficiencies brought in the stock markets by concentrated efforts of the government to uplift these markets. Thus, the crowding-out effect of stock market development emphasizes the need of developing policies which not only targets one market (stock market, in this case) but similar and simultaneous efforts are required to uplift other markets (corporate bond markets, in the present case) to prevent the flight of trades to "quality" markets.

\section{Bond Market Trends in Asia}

Asian bond markets are growing in size; however, they still lag behind the western countries, primarily the USA. In addition to this, the contribution of each Asian economy towards the total size of the Asian market is quite skewed, with only China contributing close to $51 \%$ of the total market size. China's bond market is ranked among the top bond markets of the world in terms of size; however, the market is dominated by the Government or treasury bonds and the interbank market, with only about $21 \%$ being contributed by the corporate bonds (ACRA, 2019). The Republic of Korea follows China in terms of bond market size, which is followed by Japan and India, respectively. However, Indonesia, when compared to its Asian peers' lags in size (CARE Ratings Ltd., 2018). According to the same report, however, we see the turnover ratio of the Indonesian corporate bond market is the highest in 2018, whereas Japan and China lag at the bottom. The size (measured by the stock market capitalization) of the stock markets in the above countries far exceed the size of their corporate bond markets. Japan's exchange alone has a capitalization of more than $\$ 5$ trillion (Statista, 2019), compared to their bond market size of only $\$ 700$ billion. Even in India's case, we observe a similar difference, while their bond market size was around $\$ 400$ billion, the market capitalization of BSE in 2018 was close $\$ 2$ trillion. These differences shed light on the lack of development of the corporate bond markets in comparison to the stock markets in the Asian economies.

\section{Background of the Study}

\subsection{Stock market liquidity and Bond market Liquidity}

Limited studies in the past explore the interlinkages of the stock market and bond market, especially the liquidity aspect. Volatility in the market returns primarily is positively correlated among the two markets (Fleming et al., 1998). On the other hand, there have also been studies in the past highlighting the impact of 'flight-to-quality', where the funds have moved from the stock market to the bond market on the assumption that bond markets are a safer option, especially in times of uncertainty (Bayraci et al., 2018; Connolly et al., 2005). There is consensus among the researchers about the negative return correlations among the two markets; however, when comparing the liquidity of the bond and stock markets, results have been different. While studying the relationship between the liquidity of the stock market and that of the treasury bond market, previous works have found a positive association between the two (Chordia et al., 2005). While studying the impact of monetary policy on illiquidity, Goyenko and Ukhov (2009) observed a spillover effect where a liquidity shock in the bond market was subsequently transmitted to the stock market. These studies offer insights into the liquidity relationship across markets; however, the lack of studies examining the corporate bond liquidity leaves a gap to be explored.

Liquidity becomes a critical component of any financial market, and with meagre literature that examines the liquidity of the corporate bond market, the present study attempts to bridge this gap. Studying the liquidity element of the financial markets has important implications. The trading activity has been found to have a positive correlation with the returns of the markets (Edelen and 
Warner, 2001). Level of trading activity often signals the level of confidence that investors have regarding the market conditions. Markets with higher liquidity experience lower transaction costs and enhanced market efficiency (Chordia et al., 2008). Since liquidity act as a market signal, lower liquidity in the stock market would reduce investor confidence and investors could move onto the relatively stable corporate bond market, resulting in higher trading activity in the corporate bonds.

\section{$\mathrm{H1}$ : Stock market liquidity is negatively related to corporate bond market liquidity.}

\subsection{Government Bonds Yields and Liquidity of the Corporate Bond Market}

While studying the liquidity effect on yield spreads, Chen et al. (2007) found an inverse relationship. They found higher yield spreads to be associated with more illiquid bonds, indicating that liquidity is priced in the market. These results were further backed by Favero et al. (2010), who found liquidity risk results in yield differentials in the eurozone sovereign bonds. A higher yield in the government bond market would suggest a fall in liquidity. Amihud and Mendelson (1991) highlight the implications of high yield and low liquidity in the market. Issuers would not prefer a less liquid market as they would not be able to sell securities at a desirable price. Also, they propose that investors demand less of illiquid instruments. The insights from these works suggest that a higher yield in the treasury bond market would negatively affect its desirability and would provide investors and issuers, both, an incentive to explore other markets. The negative association between the treasury bonds and corporate bonds have been explored in the work of Duffee (1998). The author found a significant negative relationship between the yields of the two markets. Results from the study show a fall in the yields of the investment-grade corporate bonds as the yields of the treasury market rises. The discussion suggests that a higher yield in the government bonds will result in a drop in corporate bond yields. Consequently, this would be associated with higher liquidity in the corporate bond market as it becomes more desirable for both investors and issuers, based on the implications provided by Amihud and Mendelson (1991). Therefore, we hypothesize a positive relationship between government bond yields and liquidity in the corporate bond market.

$\mathrm{H} 2$ : Government bond yield is positively related to corporate bond market liquidity.

\subsection{Inflation rate and Corporate Bond market liquidity}

Supply of money in the market has a positive impact on liquidity (Ariff et al., 2012). Extra supply of money in the market pushes the interest rate down, through the 'liquidity effect' (Christiano, 1991); fall in interest rates boosts the economic activity and investment, resulting in a positive effect on the trading activity in the financial markets. Inflation in an economy is a significant result of money supply shocks, with a strong positive association between the level of money and consumer prices (Browne and Cronin, 2010) and a rise in inflation signals quantitative easing. A quantitative easing strategy tends to reduce the price frictions and provides a boost to trading activity, thus having a positive impact on market liquidity (Christensen and Gillan, 2013). Thus, higher inflation rates should result in higher liquidity in the corporate bond market.

H3: Inflation rates are positively related to corporate bond market liquidity.

\section{Data and Methodology}

The study first presents the trends in turnover ratios in the Asian economies, followed by descriptive statistics. Next, to study the impact of stock market liquidity on the corporate bond market liquidity, we employed a panel dataset. Our sample consists of the top five Asian economies, ranked by GDP (IMF, 2019b) viz., China, India, Japan, Republic of Korea and Indonesia for the period 2008-2017. The model includes bond turnover ratio as the dependent variable, stock turnover ratio as independent variable and government bond yield and inflation rate as control variables. The data for all the variables have been collected on an annual basis. The proxies for variables and the respective 
sources of data collection have been explained in the following sections and summarized in Table 1.

\subsection{Measures of Liquidity}

To study the relationship between the liquidity of the stock market and the corporate bond market, we utilize the turnover ratios of the two markets for our sample Asian countries. The turnover ratio is calculated using the definition given by Asian Bonds Online, as the ratio of the total value of securities traded in the market in a year and the average market capitalization or the number of outstanding issues in the market in that year. The bond market development indicators given by World Bank lists the turnover ratio as an essential variable for testing the efficiency of the market (The World Bank, 2006). The turnover ratios have also been previously utilized by researchers to study market liquidity (Chan et al., 2007; Jun et al., 2003; Sarr and Lybek, 2002).

4.1.1 Corporate bond market liquidity (btr) -The liquidity of the corporate bond market in an economy is proxied by the corporate bond turnover ratio (btr). Corporate bond turnover ratios of the countries in our sample except for India has been extracted from the data portal of Asian Bonds Online (AsianBondsOnline, 2019). For India, the amount of trading in the corporate bond market and the number of outstanding issues in the market have been extracted from the Securities Exchange Board of India's (SEBI) 'Reports and Statistics' on corporate bonds (SEBI, 2019). For maintaining consistency, the bond turnover ratios for the same period for India have been calculated using the same definition as Asian Bonds Online.

4.1.2 Stock Market Liquidity (stock turnover) - Stock market liquidity has been proxied by the stock turnover ratio. The stock turnover ratio for all the economies in the dataset has been extracted from The World Bank's 'Global Financial Development Database' (The World Bank, 2019).

\subsection{Control variables}

4.2.1 Government Bond yields (gbond) - Yields of the 10-year Treasury bond have been taken as a proxy. The data for government bond yields have been extracted from the International Monetary Fund's (IMF) International financial statistics database for all the economies in our dataset (IMF, 2019a).

4.2.2 Inflation Rate (infperc) - The second control variable is the inflation rate, We extract inflation rates from the IMF's World Economic Outlook Database, October 2019 edition (IMF, 2019b).

\subsection{Model Specification}

\section{Table 1: Description of Variables}

\begin{tabular}{|c|c|c|c|c|}
\hline Variable & Symbol & Proxy & Role & Data Source \\
\hline $\begin{array}{l}\text { Corporate Bond } \\
\text { liquidity }\end{array}$ & btr & $\begin{array}{l}\text { Corporate bond } \\
\text { turnover ratio }\end{array}$ & $\begin{array}{l}\text { Dependent } \\
\text { Variable }\end{array}$ & $\begin{array}{l}\text { Extracted from Asian bonds } \\
\text { online and SEBI - Reports and } \\
\text { Statistics }\end{array}$ \\
\hline Stock Market Liquidity & $\begin{array}{l}\text { Stock- } \\
\text { turnover }\end{array}$ & \multirow{3}{*}{$\begin{array}{l}\text { Stock turnover } \\
\text { ratio } \\
\text { Annual yield of } \\
\text { the 10-year } \\
\text { treasury bond. } \\
\text { Annual inflation } \\
\text { rate }\end{array}$} & $\begin{array}{l}\text { Independent } \\
\text { Variable }\end{array}$ & $\begin{array}{l}\text { World Bank's Global Financial } \\
\text { Development Database }\end{array}$ \\
\hline $\begin{array}{l}\text { Government/Treasury } \\
\text { Bond market }\end{array}$ & gbond & & \multirow{2}{*}{$\begin{array}{l}\text { Control } \\
\text { Variables }\end{array}$} & $\begin{array}{l}\text { IMF's International Financial } \\
\text { Statistics }\end{array}$ \\
\hline Inflation rate & infperc & & & $\begin{array}{l}\text { IMF's World Economic Output } \\
\text { database }\end{array}$ \\
\hline
\end{tabular}

Given the panel structure of our dataset and the need to test the impact of stock market liquidity on bond market liquidity, we employ panel regression. Controlling for heteroscedasticity and autocorrelation by using Arellano specification (Arellano, 1987), the model was checked for the 
presence of fixed effects or random effects using the Hausman Test (Hausman and Taylor, 1981). The results suggested for fixed effects, and hence the same was applied. The following specification model was used:

$$
\log (\mathrm{btr})_{\mathrm{ti}}=\alpha+\beta_{1} * \log (\text { stockturnover })_{\mathrm{ti}}+\beta_{2} * \log (\text { gbond })_{\mathrm{ti}}+\beta_{3} * \log (\text { infperc })_{\mathrm{ti}}+\mu_{\mathrm{ti}}
$$

\section{Results and Analysis}

Summary statistics for the variables are reported in Table 2. The mean turnover ratio of the corporate bond market is found to be lower when compared with the stock market, and similar observation is noted for the median values. Lower liquidity in the corporate bond market across our sample indicates more activeness of the investors in the stock. The difference in the mean liquidity could point towards a lack in the development of the corporate bond market and shows how the stock market is preferred over the former. When comparing the individual countries in the sample (refer Table 3) based on the liquidity of the markets, we observe China's mean turnover ratio for the bond market is close to 2.848, much higher than all other countries in the sample, with the second-highest turnover being that of the Indonesian bond market at only 0.8. India, in comparison, lags with a mean turnover ratio of only 0.6 in the sample period. The corporate bond market of China has seen a rapid fall in its turnover ratio in the past ten years. The average turnover ratio for the first five years is found to be around 4 for the Chinese bond market, whereas for the next five years, it falls to approximately 1 . Surprisingly, in the same period, the size of the Chinese corporate bond market has seen a significant expansion, with its size in 2017 being eight times the size in 2008 (AsianBondsOnline, 2019). This observation indicates that size may not be a strong determinant of liquidity, and merely increasing the issuance will not guarantee a rise in liquidity. Figure 1 and 2 display the trends of bond turnover ratio and stock turnover ratio, respectively, of individual countries in our sample. Indian corporate bond market has not seen much variability in its turnover ratio, and it has remained almost stagnant in-sample period.

In contrast, China experienced a considerable dip in the bond turnover ratio. Rest of the economies also do not observe much variability in the bond turnover ratios. Studies that focus on the development of the Indian corporate bond market associate lack of market makers as a reason for low liquidity (Banerii et al., 2012). Indian Insurance companies and pension funds, both of which are huge players in the market and act as market makers, are restricted by mandates specified by the regulators and are permitted to invest only in bonds recognized as 'investment' grade (PFRDA, 2014; IRDAI, 2016).

Table 2: Descriptive Statistics- Overall Sample

\begin{tabular}{lcccc}
\hline & $\begin{array}{c}\text { Bond Turnover } \\
\text { Ratio }\end{array}$ & $\begin{array}{c}\text { Stock turnover } \\
\text { Ratio }\end{array}$ & $\begin{array}{c}\text { Government Bond } \\
\text { Yields }\end{array}$ & Inflation rates \\
\hline Mean & 0.996 & 1.219 & 4.814 & 3.752 \\
Median & 0.624 & 1.133 & 4.178 & 3.12 \\
Standard Deviation & 1.31 & 0.938 & 3.082 & 3.302 \\
Sample Variance & 1.717 & 0.881 & 9.498 & 10.903 \\
Minimum & 0.1 & 0.196 & -0.066 & -1.35 \\
Maximum & 5.64 & 5.569 & 12.2 & 12.314 \\
Count & 50 & 50 & 50 & 50 \\
\hline
\end{tabular}


Table 1: Descriptive Statistics - bond turnover ratio - Country-wise for the period 2008-2017

\begin{tabular}{llllll}
\hline India & \multicolumn{3}{c}{ Japan } \\
Mean & 0.61 & Mean & 2.85 & Mean & 0.14 \\
Median & 0.62 & Median & 2.56 & Median & 0.14 \\
Standard & 0.16 & Standard & 2.06 & Standard & 0.03 \\
Deviation & 0.21 & Deviation & Deviation & 0.10 \\
Minimum & 0.218 & Minimum & 0.38 & Minimum & 0.18 \\
Maximum & 0.78 & Maximum & 5.64 & Maximum & 0.18 \\
\hline
\end{tabular}

\begin{tabular}{llll}
\hline \multicolumn{3}{l}{ Republic of Korea } & Indonesia \\
\hline Mean & 0.56 & Mean & 0.82 \\
Median & 0.55 & Median & 0.85 \\
Standard & 0.10 & Standard & 0.15 \\
Deviation & 0.43 & Deviation & 0.48 \\
Minimum & Minimum & 0.96
\end{tabular}

Figure 1 - Bond Turnover Ratios of the top five Asian Economies

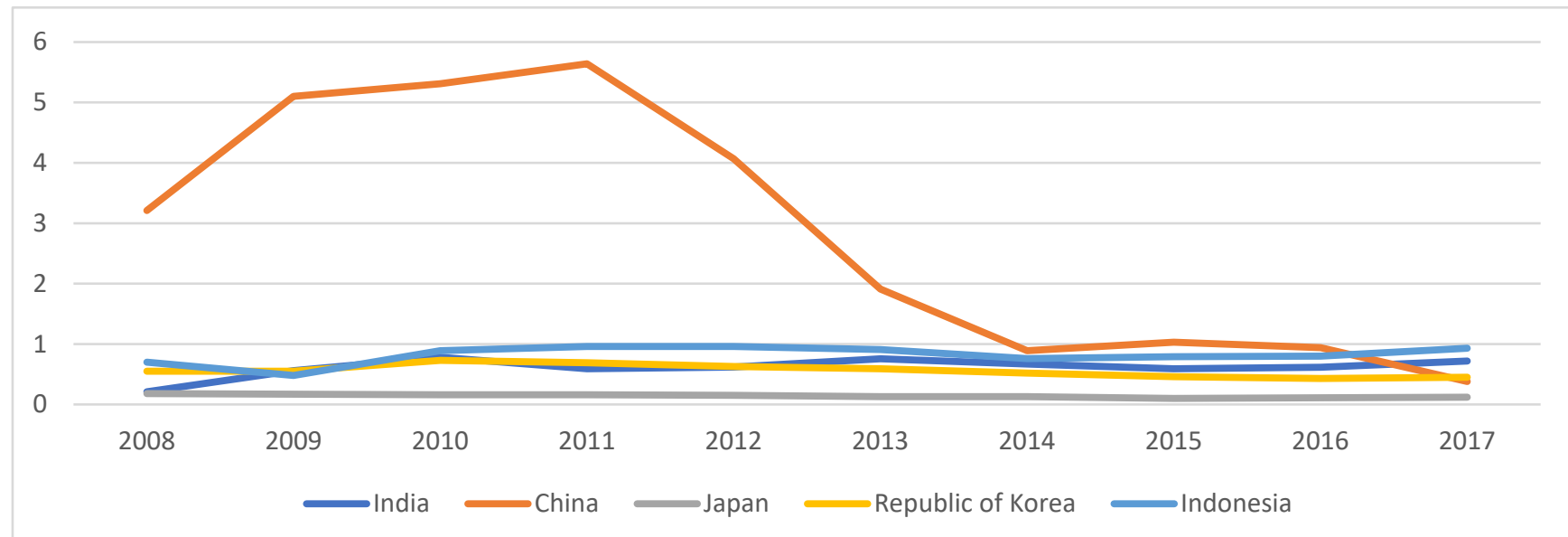

Source: Asian Bonds Online and SEBI - Reports and Statistics.

Figure 2 - Stock Turnover Ratios of the top five Asian Economies

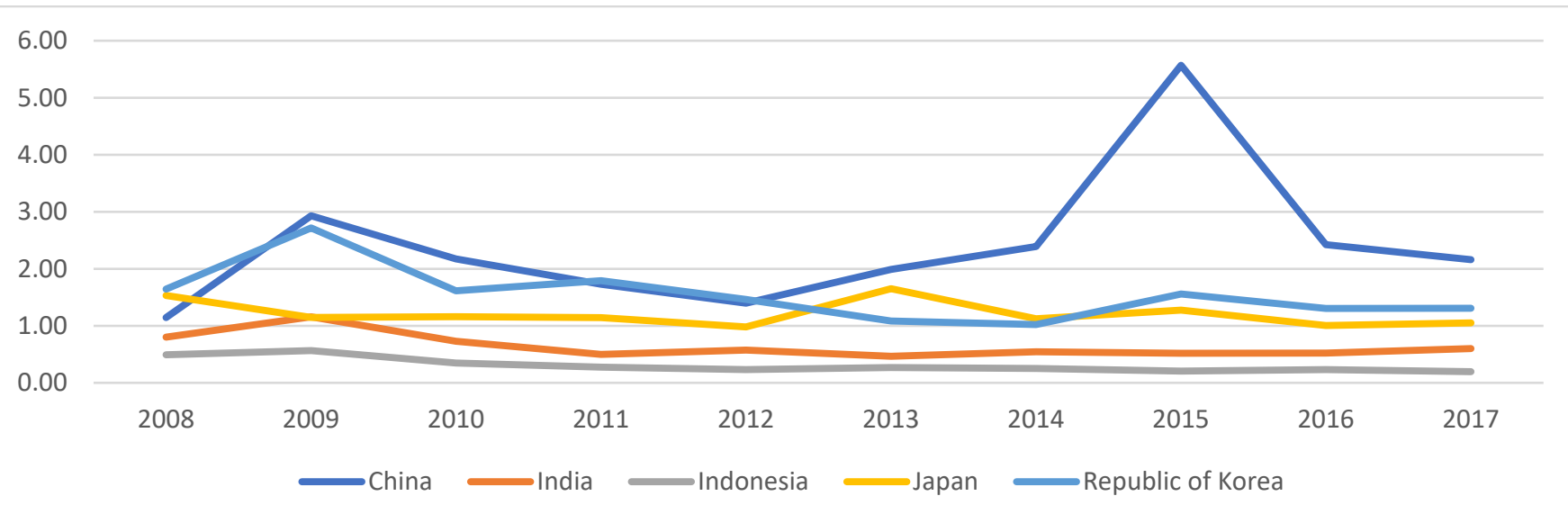

Source: World Bank - Global Financial Development Database 
Next, we applied the fixed effects model to test the impact of stock turnover ratio on bond turnover ratio; results are summarized in Table 4 . First, we ran the model, including only the dependent variable and the independent variable (omitting the control variables). Results are reported in column 2 of Table 4. It was found that the stock turnover ratio had a negative coefficient and was significant, indicating that a rise in the liquidity of the stock market would result in a fall in liquidity in the corporate bond market. However, the model resulted in a low coefficient of determination and to improve the explanatory power of the model; we included the two control variables.

\section{Table 2: Fixed effects model results}

\begin{tabular}{lll}
\hline Variables (1) & $\begin{array}{l}\text { Model with only } \\
\text { independent variable (2) }\end{array}$ & $\begin{array}{l}\text { Model with control variables and robust } \\
\text { standard errors (3) }\end{array}$ \\
\hline log(stockturnover) & $\begin{array}{l}0.0426^{*} \\
(-0.4573)\end{array}$ & $0.000^{* * *}$ \\
$(-0.5833)$ & 0.7112 \\
$\log (g$ bond) & & $(0.0467)$ \\
& & 0.0467 \\
$\log ($ infperc) & & $(0.3237)$ \\
$R^{2}$ & 0.0902 & 0.274 \\
F statistic (p-value) & $0.0426^{*}$ & $0.0086^{* *}$ \\
\hline
\end{tabular}

Note: Numbers in the parenthesis indicate respective variables estimates. ${ }^{* *},{ }^{* *},{ }^{*}$ indicate significance at $0.1 \%$, $1 \%$ and $5 \%$ levels, respectively.

With the inclusion of control variables viz. government bond yield and inflation rates, also controlling for autocorrelation and heteroscedasticity by calculating robust standard errors (reported in column 3 of Table 4), results indicate that stock turnover ratio is still highly significant and is negatively related to the bond turnover ratio. The observed negative relationship between the liquidity of the corporate bond market and the stock market is an interesting finding of the study. Whereas previous studies found stock market liquidity and treasury bond market liquidity to be moving in tandem, our results show liquidity to moving away from one market to another. The argument of 'flight-to-quality' has been previously used to explain the negative relationship between price movements in the bond market and the stock market. According to the argument, in times of market turbulence, investors prefer a stable bond market over the stock market (Ilmanen, 2003; Bayraci, Demiralay and Gencer, 2018). Fang et al. (2017) found similar results, where the level of certainty in the economy affected the correlation in the price movements among the bond and stock markets. We can extend this explanation of negative price relationship between the two markets to the negative relationship of liquidity, we observed in our results. In a stable market scenario, the trading in equity rises whereas a negative sentiment would transfer the trading activity towards the bond market, which is relatively less risky and investors look to diversify their risk (Connolly et al., 2005). Stock market liquidity is regarded as one of the predictors of the business cycle and the future state of the economy (Naes et al., 2011). Higher liquidity in the stock market is associated with a favourable economic situation and vice-versa. These observations further provide support to our results, as lower liquidity in stock market signals a relatively volatile economic situation and thus, the transfer of liquidity to the more stable bond markets. Also, another interesting aspect of the discussion is the relatively lower liquidity of the corporate bond markets. The regulations in these markets restrict particular types of investments in non-investment grade bonds which reduces the ability of institutions to trade in the market effectively and further diminishes their market-making capabilities. Due to such regulations, much of the liquidity that could have been otherwise in the bond market is being crowded out by the liquidity and hence the attractiveness of the stock market.

Our results also show a positive relationship between inflation and bond turnover ratio; however, the relationship is not found to be significant. Inflation has often been linked with the increase in money supply (Orphanides and Solow, 1990). As the money supply improves, the funds allocated to various assets improve, thereby increasing the trading activity. Money supply and liquidity have been reported in the past as having a strong positive relationship (Ariff et al., 2012), and a similar effect is 
reported in our results. Government bond yield is found to be positive but not significantly related to bond turnover ratio. Duffee (1998) found a negative relationship between the yields of the treasury bond market and the corporate bond market, as the yields in the treasury bond market increases, yields in the corporate bond market fall. Lower yields in the corporate bond market signal higher liquidity (Chen et al., 2007). In short, results from our study suggest that corporate bond market liquidity is not only affected by the liquidity in the stock markets, but their relationship is found to be inverse in nature. Higher liquidity in the stock market tends to crowd out the liquidity in the corporate bond market.

\section{Conclusion}

In our paper, we attempted to explore the nature of the relationship between the stock market liquidity and the corporate bond market liquidity. The study included a sample of the top five Asian economies for the period 2008-2017. Studies on the liquidity linkages between the bond market and stock market have been limited in the literature, and most of the research focuses on the Treasury bond markets. Our study expands on the scant literature on the corporate bond market liquidity and its relationship with the stock market. Our analysis begins with studying the levels and trends of liquidity of the stock and the corporate bond market in the countries included in our sample. It was observed that the overall corporate bond market liquidity had lagged that of the stock market. Another interesting observation made in the paper is the difference between the size of the corporate bond market and the respective liquidity. China, despite having a considerable market size, saw a fall in liquidity in the last few years.

On the other hand, Indonesia, which has the smallest bond market in the sample, had overall liquidity as the second highest in the sample, ahead of the larger markets of India and Japan. These observations signal that size alone may not be a determinant of liquidity. Further, Fixed effects model was employed to assess the impact of stock market liquidity on the corporate bond market liquidity. Even after controlling for government bond yields and inflation rate changes, a significant inverse relationship was found among the liquidity of the two markets, indicating that the liquidity of the two markets moves in the opposite direction. Thus, the results point towards a crowding-out effect, which is not explicitly explored in extant literature. Close to our present paper, the relationship between treasury bond market and the stock market has been explored in the past (Chordia et al., 2005; Goyenko and Ukhov, 2009), which has indicated a spillover effect of liquidity in the treasury bond market on liquidity in the stock market. Under this spillover effect, a liquidity shock in one market is followed by a liquidity shock in the other; however, our results indicate that a rise in liquidity in one market eats up the liquidity in the other market. The negative relationship between the liquidity of the two markets can be explained through the 'flight-to-quality' argument (Connolly et al., 2005; Bayraci et al., 2018). According to the 'flight-to-quality' explanation, any disturbance in the stock market may result in the movement of funds from the stock market to a relatively less risky market, the bond market, thereby increasing the trading activity (liquidity) in the latter market.

The fact can also support the crowding out effect of the stock market liquidity on the corporate bond market liquidity, that the Asian economies in our sample have a more liquid stock market compared to the corporate bond market, as observed through the descriptive statistics. The plausible reason for the same seems to be a lack of regulatory policies in making the bond market as lucrative as the stock market. For instance, the market regulators in India, restrict financial corporations, like the insurance companies, to invest in non-investment grade bonds, thus, hindering their ability to act as market makers (Banerji et al., 2012).

The findings of the present study support the opposing relationship between the liquidities of the stock and the corporate bond market and provide evidence of a crowding-out effect. This calls for a more concentrated effort by the regulators to develop not only one market but to have simultaneous developments in other markets as well. The paper aims to provide insights into the relatively unexplored corporate bond market liquidity, and our results bring attention to the need for 
simultaneous efforts to promote liquidity in both the markets. Policies that focus on liquidity and not just the size of the market are essential, calling for the reforms needed to boost market activity, particularly in the case of the corporate bond market. The paper aims to ignite the debate on the interlinkages between the stock market and the corporate bond market.

\section{Limitations and Future Research Scope}

The paper leaves some scope for future research. A high-frequency data of turnover ratio of the stock and corporate bond markets, besides extending the analysis to other economies for an extended sample period would shed light on more delicate nuances of the inter-linkages between the two markets. The present paper skips the impact of various economic conditions on the interlinkages between the liquidity of the two markets and is left for future researchers to explore. A comparison of developed and developing economies may provide further insights. One of the reasons for low liquidity in the corporate bond market can also be attributed to the attractiveness of the treasury bond market. Researchers may explore if a crowding-out effect exists between the corporate bond market and the treasury bond market. A model that incorporates the impact of macroeconomic factors in explaining the liquidity impact of the stock market on the corporate bond market may also be explored with a specific focus on the regulatory environment in the markets.

\section{References}

ACRA (2019) A brief introduction to China's bond market. doi: https://www.acraratings.com/research/1116.

Amihud, Y. (2002) 'llliquidity and stock returns: cross-section and time-series effects', Journal of Financial Markets, 5(1), pp. 31-56. doi: https://doi.org/10.1016/S1386-4181(01)00024-6.

Amihud, Y. and Mendelson, $H$. (1986) 'Asset pricing and the bid-ask spread', Journal of Financial Economics, 17(2), pp. 223-249. doi: https://doi.org/10.1016/0304-405X(86)90065-6.

Amihud, Y. and Mendelson, H. (1991) 'Liquidity, Asset Prices and Financial Policy', Financial Analysts Journal. Routledge, 47(6), pp. 56-66. doi: 10.2469/faj.v47.n6.56.

Arellano, M. (1987) 'Practitioners'corner: Computing robust standard errors for within-groups estimators',

Oxford Bulletin of Economics and Statistics. Wiley Online Library, 49(4), pp. 431-434.

Ariff, M., Chung, T. and Shamsher (2012) 'Money supply, interest rate, liquidity and share prices: A test of their linkage', Global Finance Journal, 23(3), pp. 202-220. doi: https://doi.org/10.1016/j.gfj.2012.10.005.

AsianBondsOnline (2019) Asian Development Bank, Asian Development Bank. Available at: https://asianbondsonline.adb.org/data-portal/.

Banerji, S. et al. (2012) New Thinking on Corporate Bond Market in India New thinking on corporate bond market in India. 106. New Delhi.

Bao, J., Pan, J. U. N. and Wang, J. (2011) 'The llliquidity of Corporate Bonds', The Journal of Finance. Wiley Online Library, 66(3), pp. $911-946$. doi: 10.1111/j.1540-6261.2011.01655.x.

Bayraci, S., Demiralay, S. and Gencer, H. G. (2018) 'Stock and Bond Co-Movements and Flight-to-Quality in G7 Countries: A Time Frequency Analysis', Bulletin of Economic Research. John Wiley \& Sons, Ltd (10.1111), 70(1), pp. E29-E49. doi: 10.1111/boer.12118.

Bhattacharyay, B. N. (2013) 'Determinants of bond market development in Asia', Journal of Asian Economics, 24, pp. 124-137. doi: 10.2139/ssrn.1898047. 
Browne, F. and Cronin, D. (2010) 'Commodity prices, money and inflation', Journal of Economics and Business, 62(4), pp. 331-345. doi: https://doi.org/10.1016/j.jeconbus.2010.02.003.

CARE Ratings Ltd. (2018) Asian Corporate Bond Market - A comparison with India. Available at: http://www.careratings.com/upload/NewsFiles/Economics/Corporate Bonds - A Comparison with India.pdf.

Chakravarty, S. and Sarkar, A. (1999) 'Liquidity in US fixed income markets: A comparison of the bid-ask spread in corporate, government and municipal bond markets', FRB of New York Staff Report, (73).

Chan, E., Ahmad, M. F. H. and Wooldridge, P. (2007) 'Liquidity in an emerging bond market: a case study of corporate bonds in Malaysia', Bank of International Settlements (BIS) Working Paper Series.

Chen, L., Lesmond, D. A. and Wei, J. (2007) 'Corporate Yield Spreads and Bond Liquidity', The Journal of Finance. John Wiley \& Sons, Ltd (10.1111), 62(1), pp. 119-149. doi: 10.1111/j.1540-6261.2007.01203.x.

Chordia, T., Roll, R. and Subrahmanyam, A. (2008) 'Liquidity and market efficiency', Journal of Financial Economics, 87(2), pp. 249-268. doi: 10.1016/j.jfineco.2007.03.005.

Chordia, T., Sarkar, A. and Subrahmanyam, A. (2005) 'An Empirical Analysis of Stock and Bond Market Liquidity', The Review of Financial Studies. New York, NY: [Oxford University Press, Society for Financial Studies], 18(1), pp. 85-129. Available at: http://www.jstor.org/stable/3598068.

Christensen, J. H. E. and Gillan, J. M. (2013) Does Quantitative Easing Affect Market Liquidity? doi: https://doi.org/10.24148/wp2013-26.

Christiano, L. J. (1991) 'Modeling the liquidity effect of a money shock', Federal Reserve Bank of Minneapolis. Quarterly Review-Federal Reserve Bank of Minneapolis. Federal Reserve Bank of Minneapolis, 15(1), p. 3.

Connolly, R., Stivers, C. and Sun, L. (2005) 'Stock Market Uncertainty and the Stock-Bond Return Relation', The Journal of Financial and Quantitative Analysis. Cambridge University Press, 40(1), pp. 161-194. Available at: http://www.jstor.org/stable/27647190.

Correia, L. and Amaral, H. (2014) 'Determinants of Market Liquidity of Shares Traded on the BM\&FBOVESPA', Brazilian Business Review, 11 (6), pp. 75-97. doi: 10.15728/bbr.2014.11.6.4.

Duffee, G. R. (1998) 'The Relation Between Treasury Yields and Corporate Bond Yield Spreads', The Journal of Finance. John Wiley \& Sons, Ltd (10.1111), 53(6), pp. 2225-2241. doi: 10.1111/0022-1082.00089.

Edelen, R. M. and Warner, J. B. (2001) 'Aggregate price effects of institutional trading: a study of mutual fund flow and market returns', Journal of Financial Economics, 59(2), pp. 195-220. doi: https://doi.org/10.1016/S0304-405X(00)00085-4.

Eichengreen, B. and Luengnarvemitchai, P. (2011) 'Why Doesn'† Asia Have Bigger Bond Markets?', SSRN Electronic Journal. Cambridge, MA. doi: 10.2139/ssrn.1009056.

Fang, L., YU, H. and Li, L. (2017) 'The effect of economic policy uncertainty on the long-term correlation between U.S. stock and bond markets', Economic Modelling, 66, pp. 139-145. doi: https://doi.org/10.1016/j.econmod.2017.06.007.

Favero, C., Pagano, M. and von Thadden, E. L. (2010) 'How Does Liquidity Affect Government Bond Yields?', Journal of Financial and Quantitative Analysis. 2009/11/26. Cambridge University Press, 45(1), pp. 107-134. doi: DOI: 10.1017/S0022109009990494.

Fink, G., Haiss, P. R. and Hristoforova, S. (2003) 'Bond Markets and Economic Growth', Europainstitut Working Paper No. 49. Available at SSRN Electronic Journal. Elsevier BV. doi: 10.2139/ssrn.1003763. 
Fleming, J., Kirby, C. and Ostdiek, B. (1998) 'Information and volatility linkages in the stock, bond, and money markets.', Journal of Financial Economics, 49(1), pp. 111-137. doi: https://doi.org/10.1016/S0304405X(98)00019-1.

Goyenko, R., Subrahmanyam, A. and Ukhov, A. (2011) 'The Term Structure of Bond Market Liquidity and Its Implications for Expected Bond Returns', Journal of Financial and Quantitative Analysis. 2010/1 1/10. Cambridge University Press, 46(1), pp. 111-139. doi: DOI: 10.1017/S0022109010000700.

Goyenko, R. and Ukhov, A. (2009) 'Stock and Bond Market Liquidity: A Long-Run Empirical Analysis', The Journal of Financial and Quantitative Analysis. [Cambridge University Press, University of Washington School of Business Administration], 44(1), pp. 189-212. Available at: http://www.jstor.org/stable/40505920.

Grossman, S. J. and Miller, M. H. (1988) 'Liquidity and Market Structure', The Journal of Finance, 43(3), p. 617. doi: 10.2307/2328186.

Gündüz, Y. et al. (2018) 'Lighting up the Dark: Liquidity in the German Corporate Bond Market', SSRN Electronic Journal. doi: 10.2139/ssrn.3253000.

Hakansson, N. H. (1999) 'The Role of a Corporate Bond Market in an Economy--and in Avoiding Crises', SSRN Electronic Journal. Elsevier BV. doi: 10.2139/ssrn.171405.

Hameed, A., Kang, W. and Viswanathan, S. (2010) 'Stock market declines and liquidity', Journal of Finance, 65(1), pp. 257-293. doi: 10.1111/j.1540-6261.2009.01529.x.

Harrison, P. (2002) 'The impact of market liquidity in times of stress on the corporate bond market: pricing, trading, and the availability of funds during heightened illiquidity', in Third Joint Central Bank Research Conference on Risk Measurement and Systemic Risk. Bank of International Settlements (BIS).

Hausman, J. A. and Taylor, W. E. (1981) 'Panel data and unobservable individual effects', Econometrica: Journal of the Econometric Society. JSTOR, pp. 1377-1398.

Heflin, F., Shaw, K. W. and Wild, J. J. (2002) 'Disclosure quality and market liquidity', Working Paper, Robert H. Smith School of Business, College Park, MD.

Hue, N. T. M. and Trâm, N. T. N. (2019) 'Bond Market Development and Economic Growth: An Empirical Study in Asia', Journal of Asian Review of Public Affairs and Policy, pp. 1-12.

Ilmanen, A. (2003) 'Stock-bond correlations', The Journal of Fixed Income. Institutional Investor Journals Umbrella, 13(2), pp. 55-66. doi: https://doi.org/10.3905/jfi.2003.319353.

IMF (2019a) International Financial Statistics, International Monetary Fund. Available at: http://data.imf.org/? sk=4C51 4D48-B6BA-49ED-8AB9-52B0C1A0179B.

IMF (2019b) World Economic Database.

IRDAI (2016) IRDAI (Investment) Regulations. India. Available at: https://www.irdai.gov.in/ADMINCMS/cms/frmGeneral_Layout.aspx?page=PageNo2934\&flag=1.

Jacoby, G., Fowler, D. J. and Gottesman, A. A. (2000) 'The capital asset pricing model and the liquidity effect: A theoretical approach', Journal of Financial Markets, 3(1), pp. 69-81. doi: https://doi.org/10.1016/S1386-4181(99)00013-0.

Jones, C. (2002) 'A Century of Stock Market Liquidity and Trading Costs', SSRN Electronic Journal. doi: 10.2139/ssrn.313681.

Jun, S. G., Marathe, A. and Shawky, H. A. (2003) 'Liquidity and stock returns in emerging equity markets', Emerging Markets Review, 4(1), pp. 1-24. doi: https://doi.org/10.1016/\$1566-0141 (02)00060-2. 
Kim, J. C., Jain, P. K. and Rezaee, Z. (2006) 'Trends and Determinants of Market Liquidity in the Pre- and Post-Sarbanes-Oxley Act Periods', in 14th Annual Conference on Financial Economics and Accounting (FEA). doi: dx.doi.org/10.2139/ssrn.488142.

Lin, H., Wang, J. and Wu, C. (2011) 'Liquidity risk and expected corporate bond returns', Journal of Financial Economics, 99(3), pp. 628-650. doi: https://doi.org/10.1016/j.jfineco.2010.10.004.

Maurya, A. K. and Mishra, O. N. (2016) 'The Macro-economic Determinants of Corporate Bond Market in India', PACIFIC BUSINESS REVIEW INTERNATIONAL, 8(12), pp. 163-176.

Mu, Y., Phelps, P. and Stotsky, J. G. (2013) 'Bond markets in Africa', Review of Development Finance, 3(3), pp. 121-135. doi: 10.1016/j.rdf.2013.07.001.

Naes, R., Skjeltorp, J. A. and Ødegaard, B. A. (2011) 'Stock Market Liquidity and the Business Cycle', Journal of Finance. John Wiley \& Sons, Ltd (10.1111), 66(1), pp. 139-176. doi: 10.1111/j.15406261.2010.01628.x.

Orphanides, A. and Solow, R. M. B. T. H. of M. E. (1990) 'Chapter 6 Money, inflation and growth', in. Elsevier, pp. 223-261. doi: https://doi.org/10.1016/\$1573-4498(05)80009-8.

Pástor, L'. and Stambaugh, R. F. (2003) 'Liquidity Risk and Expected Stock Returns', Journal of Political Economy. The University of Chicago Press, 111 (3), pp. 642-685. doi: 10.1086/374184.

PFRDA (2014) 'Revision of Investment Guidelines for NPS Schemes'. New Delhi: Penson Fund Regulatory and Development Authority. Available at: https://www.pfrda.org.in/myauth/admin/showimg.cshtmle ID=433.

Pradhan, R. P. et al. (2015) 'Bond market development and economic growth: The G-20 experience', Tékhne, 13(1), pp. 51-65. doi: https://doi.org/10.1016/j.tekhne.2015.09.003.

Romei, V. and Reed, J. (2019) 'The Asian century is set to begin', Financial Times, 26 March. Available at: https://www.ft.com/content/520cb6f6-2958-11 e9-a5ab-ff8ef2b976c7.

Sarr, A. and Lybek, T. (2002) Measuring Liquidity in Financial Markets. USA: INTERNATIONAL MONETARY FUND. doi: https://doi.org/10.5089/9781451875577.001.

SEBI (2019) Corporate Bonds - Statistics, Securities Exchange Board of India. Available at: https://www.sebi.gov.in/statistics/corporate-bonds.html.

Sharma, K. (2001) 'The Underlying Constraints on Corporate Bond Market Development in Southeast Asia', World Development, 29(8), pp. 1405-1419. doi: https://doi.org/10.1016/S0305-750X(01)00043-2.

Smaoui, H., Grandes, M. and Akindele, A. (2017) 'The Determinants of Bond Market Development: Further Evidence from Emerging and Developed Countries', Emerging Markets Review, 32, pp. 148-167. doi: https://doi.org/10.1016/j.ememar.2017.06.003.

Statista (2019) Leading stock exchanges in APAC 2018. Available at: https://www.statista.com/statistics/265236/domestic-market-capitalization-in-the-asia-pacific-region/ (Accessed: 20 January 2020).

Teplova, T. V. and Sokolova, T. V. (2018) 'Market Development Determinants for Corporate Bonds in National Currencies: Emerging Markets Review', Journal of East-West Business. Taylor \& Francis, 24(1), pp. 50-80. doi: 10.1080/10669868.2017.1340387.

The World Bank (2006) 'Financial Sector Development Indicators', pp. 1-10. Available at: http://siteresources.worldbank.org/INTTOPACCFINSER/Resources/Bndind.pdf.

The World Bank (2019) Global Financial Development. Available at: https://databank.worldbank.org/source/global-financial-development\# 